\title{
Improvement of the Quality of Business Environment Model: Case of the SME Segment
}

\author{
Jaroslav Belas $^{1}$, Jan Dvorsky ${ }^{1}, Z_{\text {denek Strnad }}{ }^{2}$, Katarina Valaskova $^{3}$, Gentjan Cera ${ }^{1}$ \\ ${ }^{1}$ Tomas Bata University in Zlin \\ Mostni 5139, Zlin 760 01, Czech Republic \\ E-mail.belas@utb.cz,j1dvorsky@utb.cz,cera@utb.cz \\ ${ }^{2}$ University of South Bohemia in Ceske Budejovice \\ Branisovska 31a, Ceske Budejovice 370 05, Czech Republic \\ E-mail.zd.strnad@seznam.cz \\ ${ }^{3}$ University of Zilina \\ Univerzitna 8215/1, Zilina 010 26, Slovak Republic \\ E-mail.katarina.valaskova@fpedas.uniza.sk \\ cross $^{\text {ref }}$ http://dx.doi.org/10.5755/j01.ee.30.5.24490
}

The aim of this article is to define important factors which determine the quality of the business environment and construct a structural model of causal relationships between quality of business environment and its determinants in small and medium sized enterprises. This model was constructed on the basis of extensive empirical research. A questionnaire was designed and delivered to SMEs operating in the Czech and Slovak Republics. The sample consists of 641 enterprises from both countries. Data were evaluated using statistical methods such as confirmation factor analysis and structural equation modeling. The structural model showed very interesting findings. The most important factors, which determine the quality of business environment, are macroeconomic environment, monetary policy and interest rates and legal environment. In our model, we also pointed out the importance of political, social and technological factors. The research results pointed to the need to adjust the legislative environment in a more appropriate way, to minimize state bureaucracy and to improve media access to business environment assessment. These results are useful for the academic researchers in the area of entrepreneurship, policymakers, and non-profit institutions and organizations whose effort is to improve the business environment and boost entrepreneurship.

Keywords: Entrepreneurship; Entrepreneurs; Slovakia; Czech Republic; Small and Medium-Sized Enterprises.

\section{Introduction}

Improving the quality of small and medium sized enterprises (SMEs) business environment is a major challenge for the European Union countries with an economic, political, technological and social dimensions. It is a logical approach, following the long-term interest in SME development of the relevant authorities not only in the European Union, but also in national economies across Europe.

Institutional environment in a country shapes the entrepreneurship, which is a significant part of the economic system of every country. On the other hand, SMEs are an important component of the economic system. It is widely recognized that entrepreneurial activity contributes to the economic growth (van Stel et al., 2005; Rajnoha \& Lorincova 2015; Belas \& Sopkova 2016; Kljucnikov et al., 2017; Lazanyi et al., 2017; Mura et al., 2017; Acs et al., 2018; Bosma et al., 2018). Therefore, improving the QBE and business climate in general can be seen as a constant concern of policymakers who design policies/strategies aimed at fostering entrepreneurship and boosting economic activity (Ohotina et al., 2018; Mackevicius et al., 2018; Cera et al., 2019).
Anchored at the institutional theory (IT) (North 1990), economic development perspective (EDP) (Wennekers et al. 2005) and resource-based view (RBV) (Barney 1991), this study seeks to investigate the effect of factors originating from outside and within the organization on Quality of Business Environment (QBE) of SMEs in the context of two countries from Central Europe. Studying the effect of these factors on QBE combining three different perspectives (IT, EDP and RBV) may give a better view over the determinants of $\mathrm{QBE}$ and provide useful insights for policymakers on how to improve it. Therefore, the current paper creates a bridge between these theoretical perspectives and entrepreneurship.

Institutional environment within the activity is performed determines the state of activity in the economy (Baumol 1990; Douhan and Henrekson 2010). This implies that the changes of the institutional framework impact entrepreneurship (Manolova et al., 2007; Chowdhury et al., 2015; Ben Letaifa \& Goglio-Primard 2016; Vojtovic 2016; Sanusi et al., 2017) by influencing on entrepreneur's decision-making. Certain legal and regulatory framework applied in the economy may constrain or enable the business activity. This can be explained through IT, which claims that the firm's decision-making is influenced by 
institutions enforced by governmental agencies and social norms (North 1990). Usually, these institutions are seen as constraints of the business activity and firm growth (Dethier et al., 2011; Krasniqi \& Desai 2016; Cera et al., 2019; Webb et al., 2019). On the other side, Balcerzak et al. (2017) highlight the impact of the efficiency of the banking sector in the European Union on the overall business environment. According to EDP, economic institutions act as a separate set of the standard institutions that influence on entrepreneurial activity (Wennekers et al., 2005; Boudreaux et al., 2019). Such institutions can be macroeconomic environment, infrastructure, access to finance etc. Scholars have seen these set of institutions as enablers of the entrepreneurial activity (Bjornskov \& Foss 2016; Boudreaux et al., 2019).

It is also acknowledged that firm performance is not determined only by factors from outside of the organization such as institutional environment and economic institutions. According to RBV, the way firm's internal resources are combined can lead to a better performance (Barney, 1991), which reflects higher QBE. The way how entrepreneurs harmonize internal available resources, such as managerial skills, human resources and assets, to create wealth influence on business activity (Sobel, 2008; Androniceanu, 2017). Therefore, factors from within the organization affect business performance and consequently the QBE. Similarly, Kliestik et al. (2018) consider the internal resources, mainly firm's goodwill as a factor for increasing firm's performance.

The originality of the current research lies in the fact that it investigates the effect of economic and noneconomic factors collectively on QBE. The non-economic factors can be political, technological and social factors.

\section{Theoretical Background}

The theoretical underpinning of the current research is built on three perspectives IT, EDP and RBV (North 1990; Barney 1991; Wennekers et al., 2005). IT and EDP deals with factors which influence on entrepreneurial activity that originates from outside the organization. Such factors are institutions that constrain or enable the business activity, over which firm do not have power to manipulate them. On the other hand, RBV advocates that firm can combine its internal resources to perform better results. As a matter of fact, internal factors can be controlled by firm management. Hence, there are two types of determinants of QBE: from outside and within the organization (Shepherd et al., 2019).

As mentioned above, the literature on entrepreneurship (Stenholm et al., 2013) and institutions (Baumol 1990; North 1990; Sobel 2008) assumes that social norms along with legislation and regulatory framework, known as institutional environments, create the conditions for individual to make decisions, which is essential in entrepreneurial cognition and the QBE (Sobel 2008; Pinho 2017; Raza et al., 2018; Luskova et al., 2018). As Douhan and Henrekson (2010) claim, institutional framework has the capacity to determines whether an activity is destructive, unproductive or productive. This leads to the fact that quality of entrepreneurship is influenced by institutional reforms by changing the environment where entrepreneurs take and implemented their decisions (Chowdhury et al., 2019).

The relationship between entrepreneurship and institutions is bidirectional (Bylund \& McCaffrey, 2017; Elert \& Henrekson, 2017). However, in the current paper it is studied the relationship that sees institutions as drivers of entrepreneurship. According to Williamson (2000), institutions can be divided into four levels. The first level consists of informal institutions (such as social norms), which are deeply rooted in society and take many years to change them. The second level is composed of formal institutions such as legislation and regulatory framework which represent the economic "rules of the game", known as the institutional environment. Competitiveness in the CEE countries is driven by gross domestic product, inflation and tax rate, foreign direct investments and trade, labor productivity and costs (Rusu \& Roman, 2018).

Institutional environment in a country shapes the entrepreneurship. Scholars have demostrated that the higher the quality of isnstitutions, the higher firm growth and QBE (Lim et al., 2010; Thai \& Turkina, 2014; Autio \& Fu, 2015; Lim et al., 2016; Peck et al., 2018). For instance, Grilli, Mrkajic and Latifi (2018) used a composite index created by factorization of these indicators: governmental effectiveness, rule of law, political stability, voice and accountability, regulatory quality, and control of corruption (Androniceanu et al., 2019). They found a positive influence of this index on venture capital activity. Almost similar results were found even by Yay et al. (2018). A study found that the low economic performance in the Europe is associated with the "excessive" production of the legislation among these countries (Marinescu, 2013). Therefore, policy formation on administrative burdens regarding SMEs and the way to boost entrepreneurship is attracting the attention of policymakers. In this line, scholars have argued that an improvement in the legal environment influence on the efficiency of the economy (Aristovnik \& Obadic, 2015; Ohanyan \& Androniceanu, 2017). According to MartinezFierro et al. (2016), government policies such as support and priorities, bureaucracy and taxes, government programmes, are significant for the entrepreneurial environment. Government regulation is perceived by entrepreneurs as major obstacle to entry in the market (Hudakova \& Masar, 2018; Lutz et al., 2010). Surprisingly, the impact of governmental regulations on start-up and business activities are not that clear (Mallett et al., 2018). Levie and Autio (2011) claim that the lighter the regulatory burden, the higher the relative prevalence of non- and strategic entrepreneurial entry, which is consistent with Bosma et al.'s (2018) findings. Country to what was expected, another study found that regulatory quality is negatively related with entrepreneurial activity (Sambharya \& Musteen, 2014). Regarding the government programs focusing at stimulating entrepreneurship, Chowdhury et al. (2019) concluded that these programs have a positive influence on QBE. Another institution that can affect business environment is the cooperation between private and public sectors. The participation of firms in a supportive program implemented by the government lead to firm growth, and on the other hand formal business network influence their growth, as well (Schoonjans et al., 
2013). Board characteristics also exhibit influence on firm performances in emerging economies (Borlea et al., 2017).

Another institution that can affect business environment is the cooperation between private and public sectors. The participation of firms in a supportive program implemented by the government lead to firm growth, and on the other hand formal business network influence their growth, as well (Schoonjans et al., 2013). In the competitiveness point of view, competitive pressures lead firms to collaborate especially in terms of costly technology application (Fernandez-Olmos \& RamirezAleson, 2017; Kot et al., 2018).

Beside formal institutions, informal ones such as social factors are critical for start-up and entrepreneurial activity and business environment (Welter \& Smallbone 2011; Dvorsky et al., 2019; Fuentelsaz et al., 2019). Family along with media and communication environments may encourage individuals to take actions to engaging in startup activities (Park et al., 2017; Sheng \& Lan, 2019). A low level of social environment reduces investment attractiveness of regions (Viturka et al., 2013). Based on the above discussion, we can conclude that $\mathrm{QBE}$ is positively associated with the quality level of the institutions in a country.

Economic institutions are often seen as a separate set of institutions which influence entrepreneurial activity (Wennekers et al., 2005; Castano et al., 2015; Boudreaux et al., 2019). This goes in line with the third level of Williamson's (2000) institutions attributed to the governance (how the game is played). This dimension of institutions consists of macroeconomic environment, access to finance, population and consumption and technology. In the following paragraphs are discussed their effect on business environment. Institutional environment affect economic growth and thereby even entrepreneurship. Similar with Lim et al.'s (2016) research, Acs et al. (2018) did a distinguish between individual-level and environmental-level variables which affect economic growth. In this line, in the current research we have factors within and outside of the organization which influence QBE. Business environment is also affected by the stakeholders' vs shareholders' interests and selected firms' governance model as visible in the study for Slovenia (Stubelj et al., 2017).

According to a study anchored at the eclectic theory of entrepreneurship (Thai \& Turkina, 2014), economic opportunities composed as an index of GDP growth, financial development, economic integration and innovation services, are important drivers of entrepreneurship. In addition, they found that economic opportunities encourage formal entrepreneurship and discourage informal one. In this context, GDP growth and per capita positively affect opportunity entrepreneurship (Fuentelsaz et al., 2019). Along with GDP growth, population consumption, income and expenditure impact business environment (Grosanu and Bota-Avram 2015). Population growth is associated with start-up activity (Lim et al., 2016) and BQE (Chowdhury et al., 2019). Another study, found a positive impact of population growth rate on informal entrepreneurship. In this regard, competitive environment should be a concern for the policymakers (Grigore \& Dragan, 2015). Entrepreneurs identify competition and rivalry in the industry as the most significant threat of their business operations (Kadocsa and Francsovics 2011; Cai and Yang 2014) .

Financial stability and access to finance are other factors that impact entrepreneurship (Ardic et al., 2012; Yang, 2017; Sayed Hussin et at., 2017; Bosma et al., 2018). Also the bankruptcy prediction has a direct impact on the entrepreneurship (Kovacova \& Kliestik, 2017). Indeed, a reliable monetary policy was mentioned by entrepreneurs as the factor which most impacts on their business operation (Buganova \& Moricova, 2018). Access to finance is likely to improve the $\mathrm{QBE}$ through driving the firms into more productive activities (Sobel 2008; Aparicio et al. 2016).

Technology advancements, human capital and infrastructure in the field of research and development are seen as drivers of entrepreneurship rates (Siqueira \& Fleury 2011; Krejci et al., 2015; Martinez-Fierro et al., 2016; Poor et al., 2018), thereby they affect QBE. Furthermore, education is an important factor that can improve the QBE (Viturka et al. 2013). Having a vocational diploma or completing higher education are likely to increase perceived opportunity, high aspiration start-up activity and firm growth (Martinez-Fierro et al., 2016; Dilli \& Westerhuis, 2018).

The fourth level of Williamson's (2000) institutions deals with resource allocation, which includes individual engagement in entrepreneurial action (Boudreaux et al., 2019). The availability of resources and the way how are they used to create wealth influence on entrepreneurial activity (Barney, 1991; Sobel, 2008). The resource-based view (RBV) suggests that combining a firm's internal resources can create a competitive advantage (Barney, 1991). Operating under a competitive advantage can lead to a better business environment. Such factors are human capital, entrepreneur's view on social environment, entrepreneur's social and emotional stances, and the firm ability to establish networks or relationships with suppliers, competitors, employees and customers.

Scholars have demonstrated that internal resources affect QBE. Resources like financial, human and social capital positively impact on new business activity (De Clercq et al., 2013). Moreover, Dunkelberg et al. (2013) argue that changes in entrepreneurs' resource goals lead to changes of the strategies of the resource-allocation. Shepherd et al. (2019) argue that between entrepreneurs' habits and venture norms there is an association. Teams' or entrepreneurs' habits or practices may lead to a source of venture norms. Thus, studying entrepreneurs' views on entrepreneurship can give insights over firms' behave, thereby, certain interconnection between entrepreneurs' views and QBE can be assumed.

If business establish and maintain good relations with its employees, suppliers, competitors and customers, then a better QBE can be reached (Skarpova \& Grosova, 2015; Fernandez-Olmos \& Ramirez-Aleson, 2017). Having good relationships with customers is identified as an influential factor affecting business activities (Kadocsa \& Francsovics 2011).

In summary, based on the three abovementioned theoretical perspectives (IT, EDP and RBV), QBE is determined by factors originated from outside (formal, 
informal and economic institutions) and within (internal resources) the organization.

\section{The Aim, Methodology and Data}

The aim of the article is to define important factors that determine the quality of the business environment and construct a structural model of causal relationships between QBE and its determinants in small and medium sized enterprises.

The attitudes of the entrepreneurs in relation to the topic of the research were obtained using an electronic questionnaire which included 82 statements [sociodemographic characteristics (6 statements); factors of business environment (72 statements) and 4 statements on the QBE]. They were formulated as a five-point Likert type scale: from 1 'totally disagree' to 5 'totally agree'. The order of questions in the questionnaire was chosen in order to obtain truthful attitudes from the respondents. The questionnaire was created in two versions based on the country of operation of the business unit. Individual companies were directly addressed by email, by phone, but also by a personal meeting. We have managed to collect 641 responses [CR: 312 (48.7\%) and SR 329 (51.3\%)]. Entrepreneurs were selected from the database "Albertina" (CR) and "Cribis" (SR) randomized numbers using mathematical functions "randbetween". Percentage of the completed questionnaire in form of positive feedback reactions was accounted for $3.5 \%$. These two countries share similar culture and economic development stage, thereby, there was no need to include country as a control variable (Cera et al., 2019).

The main article hypothesis is:

There is a statistically significant structural model of causal relationships between $Q B E$ and determined by economic (EF), political (PF), technological (TF), social $(S F)$, competitiveness $(C F)$ and relationship (FF) factors.

As discussed by other scholars (Foss et al., 2013; Stenholm et al., 2013), variables were measured as selfreport approach. Motivated by the literature of the field, we have used the same scales as Cepel et al. (2018) for the following constructs: (i) economic factors identified by four sub-dimensions: macroeconomic environment (EF1), monetary policy and interest rates (EF2), financing enterprises (EF3), population consumption, changes in income and the structure of consumer expenditure (EF4); (ii) political factors including these sub-factors: legal environment (PF1), state regulation and support of entrepreneurship (PF2), state bureaucracy (PF3), quality of education (PF4); (iii) technological factors with these subdimensions: availability of human capital (TF1); infrastructure in the area of research and development (TF2); cooperation of the private and the public sector (TF3); (iv) social factors identified by five sub-factors: entrepreneurs' views and evaluation of the social environment (SF1); family environment (SF2); media and communication environment (SF3); entrepreneurs' social (SF4) and emotional stance (SF5); (v) competitive environment (CF), and (vi) business relationships covering direct competitors, customers, suppliers, and employees (FF). The dependent variable is QBE measured as Cepel et al. (2018, p. 29) did with four indicators.

Factor analysis and structural equation modeling (SEM) were applied to meet the main goal. Exploratory FA (EFA) (Eickmeier et al. 2015) was used to: a) verify the suitability of the data (Kaiser-Meyer-Olkin test, Bartlett test) (Martinez-Lopez et al., 2013); b) factor extraction - Principal Component Analysis (PCA) and decision on number of factors (Scree graph (Shah and Goldstein 2006), component matrix; BIC - Schwarz's Bayesian information criterion (Davis-Stober et al. 2016)); c) factor rotation - method selection, factor load interpretation, Varimax (Olsson et al., 2000).

To verify of significance of the structural model, were used the FIT model characteristics: Fit model summary: Goodness of Fit (GFI); The minimum discrepancy (CMIN/DF); Comparative Fit index (CFI); Roat Mean Square Error of Approximation (RMSEA); Normed fit index (NFI); Standardized Root Mean Square Residual (SRMR); Chi-square test (Byrne and Reinhart 1989; Bentler 1990; Hooper et al. 2008). Two conditions must be met to apply the SEM method: the multidimensional normality in attitudes within manifest variables and the size of the sample set (Raykov and Marcolides 2006). Both conditions for applying the SEM method were accepted. All necessary numerical calculations and graphical visualizations were made in the SPSS Software and IBM SPSS Amos.

\section{Results}

The text is written in English with 1 interval spacing. Each paragraph should be started on a new line $(0.6 \mathrm{~cm})$.

Table 1 summarizes the test results (KMO test and Bartlett's test of sphericity), which clarify whether factor analysis is a suitable method for determining the relationship between indicators and factors.

Table 1

Results of KMO- test and Bartlett's test

\begin{tabular}{|c|c|c|}
\hline \multicolumn{2}{|c|}{ Kaiser-Meyer-Olkin Measure of Sampling Adequacy (KMO- test) } & 0.907 \\
\hline \multirow{2}{*}{$\begin{array}{c}\text { Bartlett's Test of } \\
\text { Sphericity }\end{array}$} & $\begin{array}{c}\text { Approx. Chi-Square } \\
\text { Degree of freedom (Df.) } \\
\text { P-value (Significance - Sig.) }\end{array}$ & 287.246 \\
\cline { 2 - 3 } & & 0.000 \\
\hline
\end{tabular}

Note: Acceptable values - KMO test: values around 1; Bartlett's test: Sig. lower than level of significance.

The results of the KMO-test, Bartlett's test and correlation matrixes show that the factors are not correlated with each other. The optimal number of identified factors using the very simple structure was as follows: for complexity 1 there are 15 factors, for complexity 2 the maximum number in the range of 15 to 20 factors. The number of factors by comparing models based on the BIC, resulting in a model containing 19 factors. The results obtained were satisfactory given the number of defined factors at the beginning of the research. 
Table 2

Results of Extraction Values of Square Loads

\begin{tabular}{|c|c|c|c|c|}
\hline \multirow{2}{*}{ Number of factors } & \multirow{2}{*}{ Name of factor } & \multicolumn{3}{|c|}{ Extraction values of square loads } \\
\cline { 3 - 5 } & & Total & Variance (\%) & Cumulative variance (\%) \\
\hline 1. & QBE & 3.482 & 9.176 & 10.176 \\
\hline 2. & EF1 & 3.351 & 9.108 & 26.364 \\
\hline 3. & PF2 & 2.845 & 7.078 & 32.884 \\
\hline 4. & TF2 & 2.816 & 6.522 & 39.292 \\
\hline 5. & EF2 & 2.814 & 6.408 & 54.795 \\
\hline 6. & SF5 & 2.749 & 5.503 & 50.138 \\
\hline 7. & CF & 2.708 & 5.343 & 58.559 \\
\hline 8. & EF3 & 2.702 & 4.421 & 61.980 \\
\hline 9. & SF1 & 2.486 & 3.759 & 65.279 \\
\hline 10. & TF3 & 2.417 & 3.662 & 68.550 \\
\hline 11. & EF4 & 2.386 & 3.299 & 71.551 \\
\hline 12. & SF4 & 2.293 & 3.271 & 74.092 \\
\hline 13. & PF1 & 2.155 & 3.001 & 76.477 \\
\hline 14. & TF1 & 1.979 & 2.541 & 78.685 \\
\hline 15. & FF & 1.866 & 2.385 & 79.734 \\
\hline 16. & SF2 & 1.782 & 2.208 & 80.681 \\
\hline 17. & PF3 & 1.174 & 1.049 & 81.557 \\
\hline 18. & SF3 & 1.127 & 0.947 & 0.876 \\
\hline 19. & PF4 & 1.088 & & \\
\hline
\end{tabular}

Note: The results from IBM AMOS software.

The results from Table 2 show that the selected factors explain up to $81.56 \%$ variability of the total variance. The remaining $18.46 \%$ variability of the total variance is not explained. Based on the results (Table 2) it can be concluded that all selected factors have been identified.
These results are identical to the scree graph, which also confirmed 19 factors, as the Kaiser rule (more than $1 \%$ of the total variance) achieved exactly 19 components, which we subsequently labelled as factors.

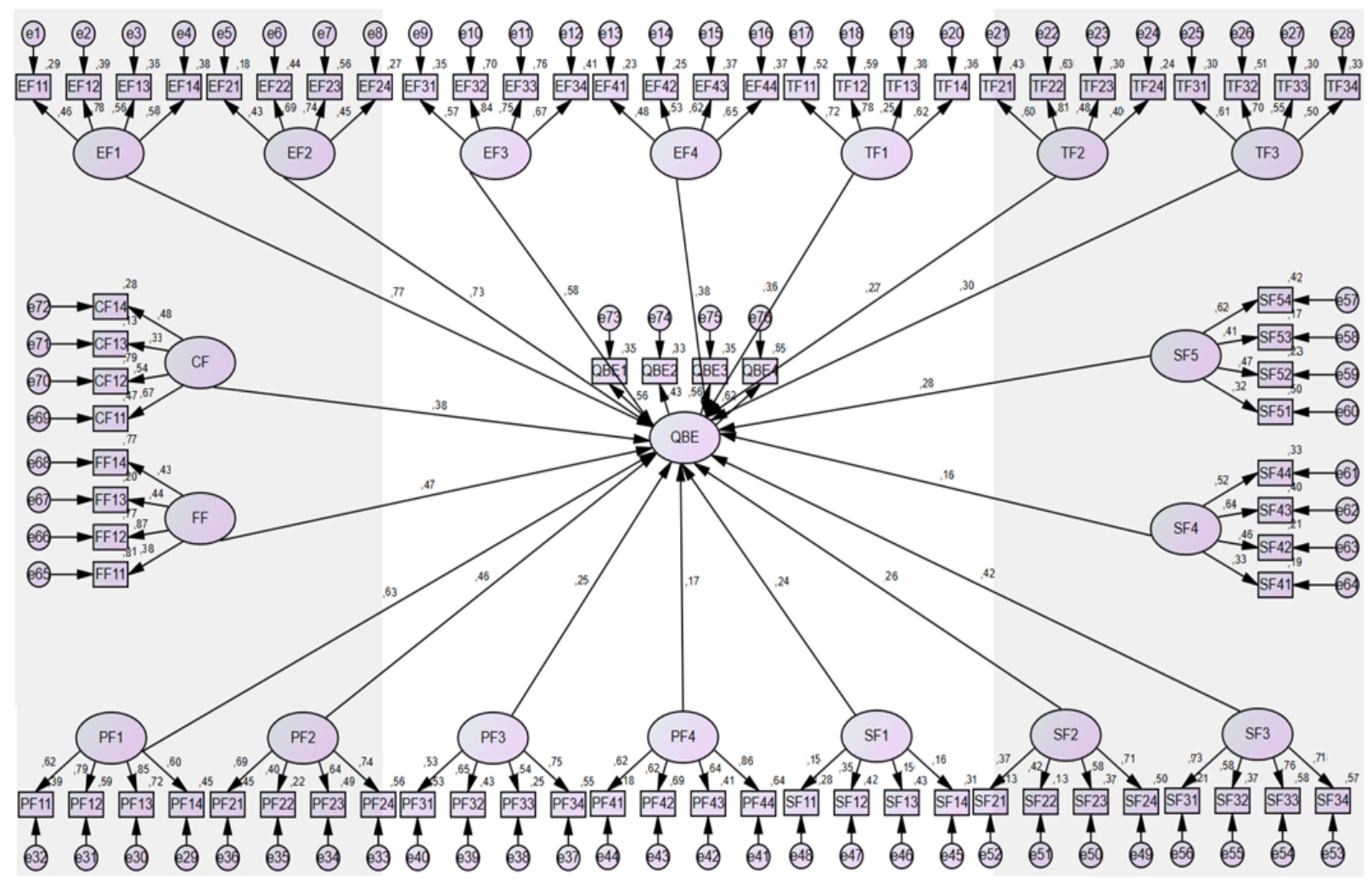

Figure 1. Structural Model with Standardized Path Estimates

The final structural model (see Figure 1) is model, where were need estimated 169 parameters, 2926 moments and 2757 number Degree of freedom. The following table 3 shows-FIT Summary of structural model. The results of FIT characteristics (Chi-Square test, CMIN/Df, RMSEA, SRMR, CFI, IFI) are positive. The results showed, that indicators have been grouped in 19 latent factors according to the results of confirmatory factor analysis. Fit Summary of structural model causal relationship between QBE and factors (see figure 1: EF, PF, TF, SF, CF and FF) are statistically significant in SME segment in CR and SR. The hypothesis is accepted. 
The Results of Structural Model Fit Summary

\begin{tabular}{|c|c|c|c|c|c|c|}
\hline Fit test & $\chi^{2}$ (p-value) & CMIN/Df & RMSEA & SRMR & CFI & IFI \\
\hline Results & 0.049 & 2.454 & 0.081 & 0.095 & 0.941 & 0.974 \\
\hline Accepted fit test & $<0.05$ & $<2.5$ & $<0.10$ & $<0.10$ & $>0.90$ & $>0.90$ \\
\hline
\end{tabular}

Note: The results from IBM AMOS software.

\section{Discussion}

The results of our research have shown that the most important influence on the formation of a QBE for SMEs are economic factors, the most important of which is the macroeconomic environment (FL: .77). Entrepreneurs stated that the state of actual macroeconomic environment of country supports starting a business, supports enterprises' innovation activities, and supports business in all and creates interesting business opportunities.

The second most important factor in our model is the monetary policy area and interest rates (FL: .73). Entrepreneurs have confirmed that the Central Bank's monetary policy has a positive impact on the business environment and stabilizes the business environment, and banks' interest rates have a positive impact on the business environment and enterprises' innovation activities.

Impact of other economic factors such as financing enterprises (access to bank loans, banks' credit conditions for entrepreneurs, and the cost of loans for enterprises), and population consumption, changes in income and the structure of consumer expenditure were less significant.

In this context, the results of our research extend the theoretical knowledge presented in the works Wennekers et al. (2005); Manolova et al. (2007); Douhan and Henrekson (2010); Chowdhury et al. (2015).

The second important area, which is significantly shaped by the quality of the SME business environment, are the political factors to which we have included legal environment (FL: .63), state regulation and support of entrepreneurship (FL: .46), state bureaucracy (FL: .25, and quality of education in the context of business needs (FL: .17). Entrepreneurs in our research have taken a negative stance on the formation of political factors of the quality of the business environment and at the same time showed the need to build this area, which corresponds to the views of Lutz et al. (2010); Martinez-Fierro et al. (2016); Grilli et al. (2018).

Technological factors to which we have included availability of human capital (FL: .36), infrastructure in the area of research and development (FL: .27), and cooperation of the private and the public sector (FL: .30) have also shown an impact on shaping a quality business environment. The greatest importance in our model has been demonstrated by the impact of the availability of human capital. On the one hand, entrepreneurs confirmed the appropriate quality of higher education in both countries, but also pointed out a lack of skilled workers for the needs of their business activities.

The results of our research are compatible with the conclusions of Siqueira and Fleury (2011); Viturka et al. (2013); Krejcí et al. (2015); Martinez-Fierro et al. (2016); Dilli and Westerhuis (2018). In this context Ivanova and Cepel (2018) state that a key factor of the states' increasing competitiveness is assumed to be the innovation performance of enterprises, which is projected through innovative business processes into the innovation performance of the economy as a whole.

In our model, we pay considerable attention to the social factors to which we have ranked entrepreneurs' views and evaluation of the social environment (FL: .24), family environment (FL: .26), media and communication environment in the context of entrepreneurial activities (FL: .42), entrepreneurs' social stance (FL: .16), and entrepreneurs' emotional stance (FL: .28).

The most important social factor that shaped the quality of the business environment was the influence of the media and how the public were informed about the business environment. On the other hand, entrepreneurs pointed out the lack of objective and correct public information, because in their opinion the media (television, broadcast, and other media) do not truthfully inform about entrepreneurship, do not help shape the quality of business environment using presentations of good business practices, and do not support entrepreneurs' communication with the public.

Our model also highlights the area of entrepreneurs' emotional stance. In our research, entrepreneurs have confirmed that they want to do business and are willing to take business risks. On the other hand they do not feel that the society appreciates them.

In this context, our findings are compatible with the views of the European Commission (2013), which states that potential entrepreneurs in Europe do not generally have a business-friendly environment. Not only is this environment problematic, it is also dominated by a culture that does not sufficiently recognize or reward entrepreneurial efforts and does not refer to successful entrepreneurs as models that create jobs and income. Europe must undergo a profound and widespread cultural change in order to drive entrepreneurship to our economy. Competitive environment (FL: .38) and narrower business environment comprises direct competitors, customers, suppliers, and employees (FL: .47.) also have an important place in our model. Entrepreneurs have stated that the level of competition is appropriate for them (competitors do not pose a significant threat to them), customers accept the prices offered and input prices are adequate, company staff and suppliers support their business.

\section{Conclusion}

The aim of the article was to design and construct a structural model of the causal relationship between the QBE and factors that determine the QBE of SMEs, influenced by three theoretical perspectives (IT, EDP, and RBV), in the context of two countries from Central Europe (Czech and Slovak Republics). 
The results showed that the economics (macroeconomic environment and monetary policy and interest rates) and political factors (legal environment), are the most important factors, which determine the QBE in SME segment. Furthermore, the current research has highlighted the important role played by non-economic factors. In the proposed model, we have demonstrated the importance of political, social and technological factors. Research has highlighted the need to adjust the legislative environment more appropriately, minimize state bureaucracy, and improve media access to the business environment assessment.

The authors are aware of the research limits (e. g. regional character of the study - only two countries, the sample size - only 641 enterprises, statistical methods factor analysis and structural equation modelling with standardized model visualization). The authors believe that this paper has brought several interesting findings and new incentives for further research and discussion regarding assessing the selected factors and their impact on the QBE in the context of SMEs.

It is worth to concentrate our future research on the comparison of the evaluation these factors according nationality of entrepreneur or level of education of entrepreneur. At the same time, we are preparing a new research project focused on research of the SME business environment in the V4 countries.

\section{References}

Acs, Z. J., Estrin, S., Mickiewicz, T., \& Szerb, L. (2018). Entrepreneurship, institutional economics, and economic growth: an ecosystem perspective. Small Business Economics, 51(2), 501-514. https://doi.org/10.1007/s11187-0180013-9

Androniceanu, A. (2017). The three-dimensional approach of Total Quality Management, an essential strategic option for business excellence, Amfiteatru Economic, 19(44), 61-78.

Androniceanu A., Gherghina, R., Ciobănașu, M. (2019). The interdependence between fiscal public policies and tax evasion, Administratie si Management Public, 32, 32-41. https://doi.org/10.24818/amp/2019.32-03

Aparicio, S., Urbano, D., \& Audretsch, D. (2016). Institutional factors, opportunity entrepreneurship and economic growth: Panel data evidence. Technological Forecasting and Social Change, 102, 45-61. https://doi.org/10.1016/j. techfore.2015.04.006

Ardic, O. P., Mylenko, N., \& Saltane, V. (2012). Access to Finance by Small and Medium Enterprises: a Cross-Country Analysis with A New Data Set. Pacific Economic Review, 17(4), 491-513. https://doi.org/10.1111/j.14680106.2012.00596.x

Aristovnik, A., \& Obadic, A. (2015). The impact and efficiency of public administration excellence on fostering SMEs in EU countries. Amfiteatru Economic, 17(39), 761-774.

Autio, E., \& Fu, K. (2015). Economic and political institutions and entry into formal and informal entrepreneurship. Asia Pacific Journal of Management, 32(1), 67-94. https://doi.org/10.1007/s10490-014-9381-0

Balcerzak, A. P., Kliestik, T., Streimikiene, D., \& Smrcka, L. (2018). Non-Parametric Approach to Measuring the Efficiency of Banking Sectors in European Union Countries. Acta Polytechnica Hungarica, 14(7), 51-70. https://doi.org/10.12700/APH.14.7.2017.7.4

Barney, J. (1991). Firm Resources and Sustained Competitive Advantage. Journal of Management, 17(1), 99-120. https://doi.org/10.1177/014920639101700108

Baumol, W. J. (1990). Entrepreneurship: Productive, Unproductive, and Destructive. Journal of Political Economy, 98(5, Part 1), 893-921. https://doi.org/10.1086/261712

Belas, J., \& Sopkova, G. (2016). A Model of Entrepreneurial Orientation. Transformation in Business \& Economics, 15(2B), 630-645.

Ben Letaifa, S., \& Goglio-Primard, K. (2016). How does institutional context shape entrepreneurship conceptualizations? Journal of Business Research, 69(11), 5128-5134. https://doi.org/10.1016/j.jbusres.2016.04.092

Bentler, P. M. (1990). Comparative fit indexes in structural models. Psychological Bulletin, 107(2), $238-246$. https://doi.org/10.1037/0033-2909.107.2.238

Bjornskov, C., \& Foss, N. J. (2016). Institutions, Entrepreneurship, and Economic Growth: What Do We Know and What Do We Still Need to Know? Academy of Management Perspectives, 30(3), 292-315. https://doi.org/10.5465/ amp.2015.0135

Borlea, N. S., Achim,V. M.,\& Mare, C. (2017) Board characteristics and firm performances in emerging economies. Lessons from Romania, Economic Research-Ekonomska Istraživanja, 30(1), 55-75. https://doi.org/10.1080/ 1331677X.2017.1291359

Bosma, N., Content, J., Sanders, M., \& Stam, E. (2018). Institutions, entrepreneurship, and economic growth in Europe. Small Business Economics, 51(2), 483-499. https://doi.org/10.1007/s11187-018-0012-x 
Jaroslav Belas, Jan Dvorsky, Zdenek Strnad, Katarina Valaskova, Gentjan Cera. Improvement of the Quality of Business...

Boudreaux, C. J., Nikolaev, B. N., \& Klein, P. (2019). Socio-cognitive traits and entrepreneurship: The moderating role of economic institutions. Journal of Business Venturing, 34(1), 178-196. https://doi.org/10.1016/j.jbusvent. 2018.08.003

Buganova, K., \& Moricova, V. (2017). Innovation of education in risk and crisis management. Turkish Online Journal of Educational Technology, 2017(November Special Issue INTE), 177-182.

Bylund, P. L., \& McCaffrey, M. (2017). A theory of entrepreneurship and institutional uncertainty. Journal of Business Venturing, 32(5), 461-475. https://doi.org/10.1016/j.jbusvent.2017.05.006

Byrne, D. G., \& Reinhart, M. I. (1989). Work characteristics, occupational achievement and the type A behaviour pattern. Journal of Occupational Psychology, 62(2), 123-134. https://doi.org/10.1111/j.2044-8325.1989.tb00483.x

Cai, S., \& Yang, Z. (2014). On the relationship between business environment and competitive priorities: The role of performance frontiers. International Journal of Production Economics, 151, 131-145. https://doi.org/10.1016/j.i jpe.2014.02.005

Castaño, M. S., Mendez, M.-T., \& Galindo, M.-A. (2015). The effect of social, cultural, and economic factors on entrepreneurship. Journal of Business Research, 68(7), 1496-1500. https://doi.org/10.1016/j.jbusres.2015.01.040

Cepel, M., Stasiukynas, A., Kotaskova, A., \& Dvorsky, J. (2018). Business environment quality index in the SME segment. Journal of Competitiveness, 10(2), 21-40. https://doi.org/10.7441/joc.2018.02.02

Cera, G., Belas, J., \& Strnad, Z. (2019). Important factors which predict entrepreneur's perception in business risk. Problems and Perspectives in Management, 17(2), 415-429. https://doi.org/10.21511/ppm.17(2).2019.32

Cera, G., Belas, J., \& Zapletalikova, E. (2019). Explaining business failure through determinist and voluntarist perspectives. Serbian Journal of Management, 14(2), 257-275. https://doi.org/10.5937/sjm14-23348

Cera, G., Breckova, P., Cera, E., \& Rozsa, Z. (2019). The effect of business enabling policies, tax treatment, corruption and political connections on business climate. Acta Polytechnica Hungarica, 16(4), 113-132. https://doi.org/10.1270 0/APH.16.4.2019.4.6

Chowdhury, F., Audretsch, D. B., \& Belitski, M. (2019). Institutions and Entrepreneurship Quality. Entrepreneurship Theory and Practice, 43(1), 51-81. https://doi.org/10.1177/1042258718780431

Chowdhury, F., Terjesen, S., \& Audretsch, D. (2015). Varieties of entrepreneurship: institutional drivers across entrepreneurial activity and country. European Journal of Law and Economics, 40(1), 121-148. https://doi.org/10. 1007/s10657-014-9464-x

Davis-Stober, C. P., Morey, R. D., Gretton, M., \& Heathcote, A. (2016). Bayes factors for state-trace analysis. Journal of Mathematical Psychology, 72, 116-129. https://doi.org/10.1016/j.jmp.2015.08.004

De Clercq, D., Lim, D. S. K., \& Oh, C. H. (2013). Individual-Level Resources and New Business Activity: The Contingent Role of Institutional Context. Entrepreneurship Theory and Practice, 37(2), 303-330. https://doi.org/10. 1111/j.1540-6520.2011.00470.x

Dethier, J. J., Hirn, M., \& Straub, S. (2011). Explaining Enterprise Performance in Developing Countries with Business Climate Survey Data. The World Bank Research Observer, 26(2), 258-309. https://doi.org/10.1093/wbro/lkq007

Dilli, S., \& Westerhuis, G. (2018). How institutions and gender differences in education shape entrepreneurial activity: a cross-national perspective. Small Business Economics, 51(2), 371-392. https://doi.org/10.1007/s11187-018-0004-x

Douhan, R., \& Henrekson, M. (2010). Entrepreneurship and second-best institutions: going beyond Baumol's typology. Journal of Evolutionary Economics, 20(4), 629-643. https://doi.org/10.1007/s00191-010-0174-4

Dunkelberg, W., Moore, C., Scott, J., \& Stull, W. (2013). Do entrepreneurial goals matter? Resource allocation in new owner-managed firms. Journal of Business Venturing, 28(2), 225-240. https://doi.org/10.1016/j.jbusvent. 2012.07.004

Dvorsky, J., Petrakova, Z., Cera, G., \& Folvarcna, A. (2019). Important factors for the entrepreneurship in Central Europe. Innovative Marketing, 15(2), 71-83. https://doi.org/10.21511/im.15(2).2019.06

Eickmeier, S., Lemke, W., \&Marcellino, M. (2015). Classical time varying factor-augmented vector auto-regressive models-estimation, forecasting and structural analysis. Journal of the Royal Statistical Society. Series A: Statistics in Society, 178(3), 493-533. https://doi.org/10.1111/rssa.12068

Elert, N., \& Henrekson, M. (2017). Entrepreneurship and Institutions: A Bidirectional Relationship. Foundations and Trends in Entrepreneurship, 13(3), 191-263. https://doi.org/10.1561/0300000073

European Commission (2013). Entrepreneurship 2020 Action plan. Communication from the commission to the European parliament, the Council, the European economic and social committee and the committee of the regions.

Fernandez-Olmos, M., \& Ramírez-Aleson, M. (2017). How internal and external factors influence the dynamics of SME technology collaboration networks over time. Technovation, 64-65, 16-27. https://doi.org/10.1016/j.technovation. 2017.06.002 
Foss, N. J., Lyngsie, J., \& Zahra, S. A. (2013). The role of external knowledge sources and organizational design in the process of opportunity exploitation. Strategic Management Journal, 34(12), 1453-1471. https://doi.org/10.10 $02 / \mathrm{smj} .2135$

Fuentelsaz, L., Gonzalez, C., \& Maicas, J. P. (2019). Formal institutions and opportunity entrepreneurship. The contingent role of informal institutions. BRQ Business Research Quarterly, 22(1), 5-24. https://doi.org/10.101 6/j.brq. 2018.06.002

Grigore, A., \& Dragan, I. (2015). Entrepreneurship and its Economical Value in a very Dynamic Business Environment. Amfiteatru Economic, 17(38), 120-132.

Grilli, L., Mrkajic, B., \& Latifi, G. (2018). Venture capital in Europe: social capital, formal institutions and mediation effects. Small Business Economics, 51(2), 393-410. https://doi.org/10.1007/s11187-018-0007-7

Grosanu, A., \& Bota-Avram, C. (2015). The influence of country-level governance on business environment and entrepreneurship: A global perspective. Amfiteatru Economic, 17(38), 60.

Hudakova, M., \& Masar, M. (2018). Assessment of the Key Business Risks of the SMEs in Slovakia and Their Comparison with other EU Countries. Entrepreneurial Business and Economics Review, 6(4), 145-160. https://doi.org/10.15678/EBER.2018.060408

Hooper, D., Coughlan, J., \& Mullen, M. R. (2008). Structural equation modelling: Guidelines for determining model fit. Electronic Journal of Business Research Methods, 6(1), 53-60.

Ivanova, E., \& Cepel, M. (2018). The Impact of Innovation Performance on the Competitiveness of the Visegrad 4 Conutries. Journal of Competitiveness, 10(1), 54-72. https://doi.org/10.7441/joc.2018.01.04

Kadocsa, G., \& Francsovics, A. (2011). Macro and micro economic factors of small enterprise competitiveness. Acta Polytechnica Hungarica, 8(1), 23-40.

Kliestik, T., Kovacova, M., Podhorska, I., \& Kliestikova, J. (2018). Searching for Key Sources of Goodwill Creation as New Global Managerial Challenge. Polish Journal of Management Studies, 17(1), 144-154. https://doi.org/10.175 12/pjms.2018.17.1.12

Kljucnikov, A., Kozubikova, L., \& Sopkova, G. (2017). The Payment Discipline of Small and Medium-sized Enterprises. Journal of Competitiveness, 9(2), 45-61. https://doi.org/10.7441/joc.2017.02.04

Kot, S., Goldbach, I. R., \& Slusarczyk, B. (2018). Supply chain management in SMES - Polish and Romanian approach, Economics and Sociology, 11 (4), 142-156. https://doi.org/10.14254/2071-789X.2018/11-4/9

Kovacova, M., \& Kliestik, T. (2017). Logit and Probit application for the prediction of bankruptcy in Slovak companies. Equilibrium. Quarterly Journal of Economics and Economic Policy, 12(4), 775-791. https://doi.org/10.241 36/eq.v12i4.40

Krasniqi, B. A., \& Desai, S. (2016). Institutional drivers of high-growth firms: country-level evidence from 26 transition economies. Small Business Economics, 47(4), 1075-1094. https://doi.org/10.1007/s11187-016-9736-7

Krejcí, M., Strielkowski, W., \& Cabelkova, I. (2015). Factors that influence the success of small and medium enterprises in ICT: a case study from the Czech Republic. Verslas: Teorija Ir Praktika, 16(3), 304-315. https://doi.org/10. 3846/btp.2015.521

Lazanyi, K., Virglerova, Z., Dvorsky, J., \& Dapkus, R. (2017). An Analysis of Factors Related to "Taking Risks", according to Selected SocioDemographic Factors. Acta Polytechnica Hungarica, 14(7), 35-50. https://doi.org/10.12 700/APH.14.7.2017.7.3

Levie, J., \& Autio, E. (2011). Regulatory Burden, Rule of Law, and Entry of Strategic Entrepreneurs: An International Panel Study. Journal of Management Studies, 48(6), 1392-1419. https://doi.org/10.1111/j.1467-6486.2010.01006.x

Lim, D. S. K., Morse, E. A., Mitchell, R. K., \& Seawright, K. K. (2010). Institutional Environment and Entrepreneurial Cognitions: A Comparative Business Systems Perspective. Entrepreneurship Theory and Practice, 34(3), 491-516. https://doi.org/10.1111/j.1540-6520.2010.00384.x

Lim, D. S. K., Oh, C. H., \& De Clercq, D. (2016). Engagement in entrepreneurship in emerging economies: Interactive effects of individual-level factors and institutional conditions. International Business Review, 25(4), 933-945. https://doi.org/10.1016/j.ibusrev.2015.12.001

Luskova, M. , Titko, M. , O'Connor, A. (2018). Societal vulnerability to impacts of extreme weather events on land transport infrastructure. Communications - Scientific Letters of the University of Zilina, 20(2), 62-67.

Lutz, C. H. M., Kemp, R. G. M., \& Dijkstra, S. G. (2010). Perceptions regarding strategic and structural entry barriers. Small Business Economics, 35(1), 19-33. https://doi.org/10.1007/s11187-008-9159-1

Mackevicius, J., Sneidere, R., \& Tamuleviciene, D. (2018). The waves of enterprises bankruptcy and the factors that determine them: the case of Latvia and Lithuania. Entrepreneurship and Sustainability Issues, 6(1), $100-114$. https://doi.org/10.9770/jesi.2018.6.1(8) 
Manolova, T. S., Eunni, R. V., \& Gyoshev, B. S. (2007). Institutional Environments for Entrepreneurship: Evidence from Emerging Economies in Eastern Europe. Entrepreneurship Theory and Practice, 32(1), $203-218$. https://doi.org/10.1111/j.1540-6520.2007.00222.x

Marinescu, C. (2013). Institutional quality of the business environment: Some european practices in a comparative analysis. Amfiteatru Economic, 15(33), 270-287.

Martínez-Fierro, S., Biedma-Ferrer, J. M., \& Ruiz-Navarro, J. (2016). Entrepreneurship and strategies for economic development. Small Business Economics, 47(4), 835-851. https://doi.org/10.1007/s11187-016-9738-5

Martinez-Lopez, F. J., Gazquiz-Abad, J. C., Sousa, C. M. P. (2013). Structural equation modelling in marketing and business research: Critical issues and practical recommendations. European Journal of Marketing, 47(1/2), 115-152. https://doi.org/10.1108/03090561311285484

Mura, L., Kljucnikov, A., Tvaronaviciene, M., Androniceanu, A. (2017). Development trends in human resource management in small and medium enterprises in the Visegrad group. Acta Polytechnica Hungarica, 14(7), $105-122$. https://doi.org/10.12700/APH.14.7.2017.7.7

North, D. C. (1990). Institutions, institutional change, and economic performance. Cambridge University Press. https://doi.org/10.1017/CBO9780511808678

Ohotina, A.; Lavrinenko, O., Gladevich, J., \& Lazdans, D. (2018). The investment climate in Latvia's, Lithuania's and Belarus's cross-border regions: the subjective-objective assessment. Entrepreneurship and Sustainability Issues,6(2), 767-780. https://doi.org/10.9770/jesi.2018.6.2(20)

Olsson, U. H., Foss, T., Troye, S. V., \& Howell, R. D. (2000). The performance of ML, GLS, and WLS estimation in structural equation modeling under conditions of misspecification and nonnormality. Structural Equation Modeling, 7(4), 557-595. https://doi.org/10.1207/S15328007SEM0704_3

Ohanyan, G., Androniceanu, A. (2017). Evaluation of IMF program effects on employment in the EU. Acta Oeconomica, 67(3), 311-332. https://doi.org/10.1556/032.2017.67.3.2

Park, J., Sung, C., Im, I., Park, J. Y., Sung, C. S., \& Im, I. (2017). Does Social Media Use Influence Entrepreneurial Opportunity? A Review of its Moderating Role. Sustainability, 9(9), 1593. https://doi.org/10.3390/su9091593

Peck, F., Jackson, K., \& Mulvey, G. (2018). Regulation and growth-oriented small businesses in North-West England. Journal of Small Business and Enterprise Development, 25(2), 294-312. https://doi.org/10.1108/JSBED-07-20170232

Pinho, J. C. (2017). Institutional theory and global entrepreneurship: exploring differences between factor- versus innovation-driven countries. Journal of International Entrepreneurship, 15(1), 56-84. https://doi.org/10.1007/s $10843-016-0193-9$

Poor, J., Juhasz, T., Machova, R., Bencsik, A., \& Bilan, S. (2018). Knowledge management in human resource management: Foreign-owned subsidiaries' practices in four CEE countries. Journal of International Studies, 11(3), 295-308. https://doi.org/10.14254/2071-8330.2018/11-3/23

Rajnoha, R., \& Lorincova, S. (2015). Strategic Management of Business Performance Based on Innovations and Information Support in Specific Conditions of Slovakia. Journal of Competitiveness Vol. 7, Issue 1, pp. 3-21. https://doi.org/10.7441/joc.2015.01.01

Raykov, T., Marcolides, A. (2006). A First Course in Structural Equation Modeling, (2nd Ed.) London: Erlbaum.

Raza, A., Muffatto, M., \& Saeed, S. (2018). The influence of formal institutions on the relationship between entrepreneurial readiness and entrepreneurial behaviour. Journal of Small Business and Enterprise Development. https://doi.org/10.1108/JSBED-01-2018-0014

Rusu, D. V., \& Roman, A. (2018). An empirical analysis of factors affecting competitiveness of C.E.E. countries, Economic Research-Ekonomska Istrazivanja, 31(1), 2044-2059. https://doi.org/10.1080/1331677X.2018.1480969

Sambharya, R., \& Musteen, M. (2014). Institutional environment and entrepreneurship: An empirical study across countries. Journal of International Entrepreneurship, 12(4), 314-330. https://doi.org/10.1007/s10843-014-0137-1

Sanusi, K. A., Meyer, D., \& Slusarczyk, B. (2017). The relationship between changes in inflation and financial development. Polish Journal of Management Studies, 16 (2), 253-265. https://doi.org/10.17512/pjms.2017.16.2.22

Sayed Hussin, S. A. H., Iskandar, T. M., Saleh, N. M., \& Jaffar, R. (2017). Professional Skepticism and Auditors' Assessment of Misstatement Risks: The Moderating Effect of Experience and Time Budget Pressure. Economics and Sociology, 10(4), 225-250. https://doi.org/10.14254/2071-789X.2017/10-4/17

Schoonjans, B., Cauwenberge, P. Van, \& Bauwhede, H. Vander. (2013). Formal business networking and SME growth. Small Business Economics. https://doi.org/10.1007/s11187-011-9408-6

Sheng, J., \& Lan, H. (2019). Business failure and mass media: An analysis of media exposure in the context of delisting event. Journal of Business Research, 97, 316-323. https://doi.org/10.1016/j.jbusres.2018.01.055 
Shepherd, D. A., Wennberg, K., Suddaby, R., \& Wiklund, J. (2019). What Are We Explaining? A Review and Agenda on Initiating, Engaging, Performing, and Contextualizing Entrepreneurship. Journal of Management, 45(1), $159-196$. https://doi.org/10.1177/0149206318799443

Siqueira, A. C. O., \& Fleury, M. T. L. (2011). Complementarities of human capital and information technology: small businesses, emerging economy context and the strategic role of firm resources. Technology Analysis \& Strategic Management, 23(6), 639-653. https://doi.org/10.1080/09537325.2011.585032

Shah, R., \& Goldstein, S. M. (2006). Use of structural equation modeling in operations management research: Looking back and forward. Journal of Operations Management, 24(2), 148-169. https://doi.org/10.1016/j.jom.2005.05.001

Skarpova, L., \& Grosova, S. (2015). The Application of Business Network Approach for Small and Medium Enterprises (SME) with regard to their Buying Behavior. Journal of Competitiveness, 7(3), 62-74. https://doi.org/10.7441/ joc.2015.03.05

Sobel, R. S. (2008). Testing Baumol: Institutional quality and the productivity of entrepreneurship. Journal of Business Venturing, 23(6), 641-655. https://doi.org/10.1016/j.jbusvent.2008.01.004

Stenholm, P., Acs, Z. J., \& Wuebker, R. (2013). Exploring country-level institutional arrangements on the rate and type of entrepreneurial activity. Journal of Business Venturing, 28(1), 176-193. https://doi.org/10.1016/j.jbusvent.2011. 11.002

Stubelj,I., Dolenc,P., Biloslavo, R., Nahtigal, M., \& Laporsek, S. (2017) Corporate purpose in a small post-transitional economy: the case of Slovenia, Economic Research-Ekonomska Istraživanja, 30(1), 818-835. https://doi.org/10. 1080/1331677X.2017.1311230

Thai, M. T. T., \& Turkina, E. (2014). Macro-level determinants of formal entrepreneurship versus informal entrepreneurship. Journal of Business Venturing, 29(4), 490-510. https://doi.org/10.1016/j.jbusvent.2013.07.005

van Stel, A., Martin, C., \& Thurik, R. (2005). The Effect of Entrepreneurial Activity on National Economic Growth. Small Business Economics, 24, 311-321. https://doi.org/10.1007/s11187-005-1996-6

Viturka, M., Wokoun, R., Krejcova, N., Tonev, P., \& Zitek, V. (2013). The regional relationship between quality of business and social environment: harmony or disharmony? E+M Ekonomie a Management, 16(2), 22-40.

Vojtovic, S. (2016). The Impact of the Structural Funds on Competitiveness of Small and Medium-Sized Enterprises. Journal of Competitiveness, 8(4), 30 -45. https://doi.org/10.7441/joc.2016.04.02

Webb, J. W., Khoury, T. A., \& Hitt, M. A. (2019). The Influence of Formal and Informal Institutional Voids on Entrepreneurship. Entrepreneurship Theory and Practice, 1-23. https://doi.org/10.1177/1042258719830310

Welter, F., \& Smallbone, D. (2011). Institutional Perspectives on Entrepreneurial Behavior in Challenging Environments. Journal of Small Business Management, 49(1), 107-125. https://doi.org/10.1111/j.1540-627X.2010.00317.x

Wennekers, S., van Wennekers, A., Thurik, R., \& Reynolds, P. (2005). Nascent Entrepreneurship and the Level of Economic Development. Small Business Economics, 24(3), 293-309. https://doi.org/10.1007/s11187-005-1994-8

Williamson, O. E. (2000). The New Institutional Economics: Taking Stock, Looking Ahead. Journal of Economic Literature, 38(3), 595-613. https://doi.org/10.1257/jel.38.3.595

Yang, J. S. (2017). The governance environment and innovative SMEs. Small Business Economics, 48(3), 525-541. https://doi.org/10.1007/s11187-016-9802-1

The article has been reviewed.

Received in November 2019; accepted in December 2019. 